\title{
Awareness of Parents Having School Age Children with Enuresis
}

\author{
Nora Mohamed Abd-Elrazik Khalil ${ }^{(1)}$, Omayma Abu Bakr ${ }^{(2)}$, Hanaa EzzEldin Prince ${ }^{(3)}$ \\ (1) B. Sc., nursing, Faculty of Nursing - Ain Shams University \\ (2) Professor of Psychiatric Mental Health Nursing, Faculty of Nursing - Ain Shams University \\ (3) Lecturer of Psychiatric Mental Health Nursing, Faculty of Nursing - Ain Shams University
}

\begin{abstract}
Aim of the study the aim of this study is to assess awareness of parents having school age children with enuresis. Research design descriptive exploratory research design was used to achieve the aim of the current study. The setting of the study the study was conducted at children outpatient clinics of Elkhanka psychiatric and mental health hospital at El-kaliobia. Subjects the sample was convenient sample, composed of 240 parents having school age children with enuresis. Tools used for data collection: first tool: socio-demographic interviewing questionnaire sheet including (aSocio-demographic data characteristics for children with enuresis and for parents having children with enuresis, b- Physical, psychological and social assessment sheet of the child answered by parents) prepared by the researcher, second tool: questionnaire sheet about awareness of parents having children with enuresis include (knowledge, attitude and practice) prepared by the researcher. The study results revealed that, parents total level of knowledge about enuresis results that average knowledge, parents having school age children suffering from enuresis total level of attitude about enuresis results that natural attitude and parents having school age children suffering from enuresis shows that incompetent practice. Furthermore, there was statistically significant correlation between total score of knowledge, attitude and practice. Conclusion nearly less than two third of parents having school age children suffering from enuresis have average level of knowledge, more than half of parents having school age children with enuresis have natural level of attitude, and more than two third of them are incompetent practice. Recommendations the study recommended that establishing educational health programs for parents having children with enuresis, establishing training programs for parents to modify their behaviors when dealing with their children with enuresis.
\end{abstract}

Keywords: Awareness, parents of school age children, enuresis

\section{INTRODUCTION}

The word enuresis is derived from a Greek word (enourein) that means "to void urine." It can occur either during the day or at night. Raveena, (2019), it can be defined as an intermittent incontinence in a child being at least five years old. For the diagnosis of enuresis to be established, a child five to six years old should have two or more bed-wetting episodes per month, and a child older than six years of age should have one or more bed-wetting episode per month. Alshahrani, Selim, \& Abbas, (2018) bedwetting is more common in boys-and in all children whose parents wet the bed when they were young. Your child's chances of wetting the bed are about 1 in 3 when one parent was affected as a child. If both parents were affected, the chances that your child will wet the bed are 7 in 10 (Tu, Baskin, 2016).

Some of disorders that facing children are loss of confidence, poor school achievement and difficulty in making friends. The impact of bed-wetting as an adverse life event was comparable to poor academic attainment These results could be interpreted as nocturnal enuresis is profoundly affects the child's life socially, emotionally, and behaviorally and also impacts the everyday life of his/her family. (Elbahnasawy \& Elnagar, 2015),

So parental awareness toward a child's bed-wetting can make the difference in how a child feels about his bed-wetting problem and himself.It is a common belief among parents that bedwetting will eventually resolve with age and, as a result, many parents delay seeking treatment for bedwetting until it is having a considerable impact on the child and family (Tai, Tai, Chang \& Huang 2017).

Parents should understand the problem of enuresis, because their role is essential to success in the process of management. They should take responsibility for helping the child to learn the skill of being dry. Mothers are the main caregivers for their children (Meydan, 
Civilibal, Elevli, Duru, \& Civilibal, 2012). Parents with an ambivalent attitude towards their child's bedwetting have mixed feelings about a situation that they believe can probably only be finally changed by the young person. They believe that the young person may have more control over the situation than he or she is choosing to exercise, yet at the same time they are perplexed that the young person does not exercise the control that they may have to combat the negative social consequences of bedwetting (Odususi \& Afolabi, 2019).

Psychosocial support is an essential part of stress care which is a psychological burden on mothers. It is important for the mothers to understand that the child is not alone. The child should be included in the treatment plan; this helps increase the child's motivation to become dry and discuss potential strategies with the family to reduce stressors on the child or to help the child cope with the stressors (Anyanwu, Ibekwe \& Orji 2015).

Different models can be applied in the nursing care of the child and his/her family. Family centered care is based on the patient empowerment literature and has also gained inspiration from salutogenic and systems theory. Family centered care promotes a relationship based on partnership between the nurse and the family, who in turn are viewed as an interconnected system where processes affecting one-member spill over to other members (Mastro, Flynn, Millar, DiMartino, Ryan \& Stein. 2019).

\section{Significance of the study}

The prevalence of enuresis has been reported up to 200 in 1000 in five year old children and it is more common in boys (Boryri, et al., 2016) and the incidence percentage are $10-33 \%$ of $5-6$ year olds bed wet, $8-15 \%$ of $7-8$ year olds bed wet and Less than $5 \%$ of those older than 10 years of age bed wet (Preston Smith, 2016).

Surveys have found that $25 \%$ to $33 \%$ of parents punished their children for wetting the bed, and in some cases punishment involved physical abuse. If a parent or caregiver states that the child is deliberately wetting the bed, potential abuse should be considered. Parents or caregivers who blame or express anger or negativity toward the child may need additional support in coping, and the intervention of a pediatric specialist may be necessary ( $\mathbf{T u}$, Baskin and Arnhym, 2017).

Aim of the study:

Therefore, this study aimed to assess the awareness of parents having school age children with enuresis through:

1. Assessing the parent's knowledge about enuresis.

2. Assessing the parent's attitude toward care their children with enuresis.

3. Assessing the parent's practice towards enuresis.

\section{Research Questions:}

- What is the knowledge of parents having school age children with enuresis?

- What is the attitude of parents having school age children with enuresis?

- What is the practice of parents having school age children with enuresis?

\section{SUBJECTS AND METHODS}

Subjects and methods of this study were portrayed under four main topics as follows:

I. Technical design

II. Operational design

III. Administrative design

IV. Statistical design

\section{Technical Design}

The technical design for this study Include research design, setting, subjects and tools of data collection.

\section{1) Research Design:}

Descriptive exploratory research design was used to achieve the current study.

\section{2) Research Setting:}

This study was conducted in outpatient children clinics, at ElKhanka for psychiatric and mental health hospital, the place is composed of rest for patients, office for the nurses and five clinics every clinic has a doctor. 


\section{SUBJECTS OF THE STUDY}

The subject of this study will include 240 parents having school age children with enuresis.

Sample type: convenient sample.

Sample Size: Study subjects include a representative of total children in outpatient clinic attendance rate $(\mathrm{N}=967)$ at Elkhanka for psychiatric and mental health hospital; were hospitalized during the period 2017. Based on sample size equation 240 parents will be participated in the study. So, the sample size was calculated by adjusting the power of the test to $80 \%$ and the confidence interval to $95 \%$ with margin of error accepted adjusted to $5 \%$ and a known total population of 240 parents using the following equation:

- $\quad$ Type I error $(\alpha)=0.05$

- $\quad$ Type II error $(B)=0.2$

- With power of test 0.80

$$
240=\left[\frac{967 \times 0.30(1-0.30)}{\left.\left[967-1 \times\left(0.05^{2} \div 1.96^{2}\right)\right]+0.30(1-0.30)\right]}\right]
$$

$\mathrm{N}=$ Community size

$\mathrm{z}=$ Class standard corresponding to the level of significance equal to 0.95 and 1.96

$\mathrm{d}=$ The error rate is equal to 0.05

$\mathrm{p}=$ Ratio provides a neutral property $=0.30$

(Chow, Shao, \& Wang, 2007)

\section{Tools of data collection:}

\section{Socio-demographic}

interviewing questionnaire sheet: It was designed by the researcher to collect data. It consists of two parts:-

A. Socio-demographic data characteristics: for children with enuresis contains (Age, Sex, Weight, Sex of siblings, The order of the child between brothers and sisters, The number of times of enuresis per week, When the child urinates involuntarily, Does he go to school?, Does the child urinate involuntarily at school? Is the child punished for urinating by teachers? ). For parents having children with enuresis (Parent responsible for care of child,
Residence, Parents education level, Is family income..., Parent's work, Parent's age, Does the mother suffer from a chronic disease that causes constant stress while caring for the child?, If the answer is yes, indicate the type of disease, Does one of the brothers suffer from enuresis ?, Is the bathroom located far from the child's room?, Is there enough lighting at night near the bathroom and the baby room?).

B. Assessment questionnaire designed by the researcher to assess the Physical (16 questions), psychological, (19 questions) and social assessment of the child (11 questions) answered by parents.

Scoring System:
\begin{tabular}{|l|l|l|}
\hline \multicolumn{1}{|c|}{ Scoring } & \multicolumn{2}{|c|}{ score range } \\
\hline \multicolumn{1}{|c|}{ items } & $16-32$ grades. \\
\hline $\begin{array}{l}\text { Physical assessment } \\
\text { (16 items) }\end{array}$ & \multicolumn{2}{|c|}{$19-38$ grades. } \\
\hline $\begin{array}{l}\text { Psychological } \\
\text { assessment } \\
\text { (19 items) }\end{array}$ & \multicolumn{2}{|c|}{$11-22$ grades } \\
\hline $\begin{array}{l}\text { Social assessment }(\mathbf{1 1} \\
\text { items) }\end{array}$ & $\begin{array}{l}\text { Low } \\
\text { level }\end{array}$ & High level \\
Total score & $\leq \mathbf{5 0 \%}$ & $>\mathbf{5 0}: \leq \mathbf{1 0 0} \%$ \\
\hline $\begin{array}{l}\text { Physical, Psychological } \\
\text { and Social assessment }\end{array}$ & \multicolumn{2}{|c|}{} \\
\hline
\end{tabular}

II. Awareness of parents having children with enuresis. This questionnaire was developed by the researcher to assess the three domains:-

1. Knowledge assessment. (14 questions), including rating ranging from 1 to 3 with a higher score reflecting a satisfied for each item. Each question response was either agree (3 grade), disagree (2) and do not know (1 grade).

2. Attitude assessment. (20 questions). including rating ranging from 1 to 3 with a higher score reflecting a positive attitude for each item, while 5 items negative attitude, its answers have a three-point response likert scale, from 1 (never), 2(sometimes) and 3 (always). 
3. Practice assessment.(31 questions) including rating ranging from 1 to 3 with a higher score reflecting always for each item, while 13 items negative practice, its answers have a three-point response Likert scale, from 1 (never), 2 ( sometime) and 3 (always).

\section{Scoring System:}

\begin{tabular}{|c|c|c|}
\hline items & Range & score \\
\hline \multirow{3}{*}{$\begin{array}{l}\text { Knowledge } \\
\text { assessment } \\
\text { (32 items) }\end{array}$} & Poor & $\begin{array}{l}32: 47.9 \\
(<50 \%)\end{array}$ \\
\hline & Average & $\begin{array}{l}48: 72.9 \\
(50-75 \%) \\
\end{array}$ \\
\hline & Good & $\begin{array}{l}73: 96 \\
(>75-100 \%)\end{array}$ \\
\hline \multirow{3}{*}{$\begin{array}{ll}\text { 2. Attitude } \\
\text { assessment } \\
(20 \text { items })\end{array}$} & Negative & $\begin{array}{l}20: 29.9 \\
(<50 \%)\end{array}$ \\
\hline & Natural & $\begin{array}{l}30: 45.8 \\
(50-75 \%)\end{array}$ \\
\hline & Positive & $\begin{array}{l}45.9: 60 \\
(50-75 \%)\end{array}$ \\
\hline \multirow{2}{*}{$\begin{array}{cc}\text { 3. } & \text { Practice } \\
\text { assessment } \\
(31 \text { items })\end{array}$} & Competent & \begin{tabular}{|l|}
$31: 55.8$ \\
$(<60 \%)$ \\
\end{tabular} \\
\hline & Incompetent & $\begin{array}{l}55.9: 93 \\
(>60 \%) \\
\end{array}$ \\
\hline
\end{tabular}

\section{Operational design:}

The operational design for this study contains three phases namely: the preparatory phase,Validity and reliability, pilot study, and fieldwork.

\section{1-The Preparatory phase:}

This phase started with a review of current and past, national and international related literature concerning the subjects of the study, using textbooks, articles, journals, and websites. This review was helpful to the researcher in reviewing and selects the data collection tool.

\section{2-Validity and reliability of tool}

To achieve the criteria of trustworthiness of the tools of data collection in this study, the tools were tested and evaluated for their face and content validity, by jury group consisting of experts from nursing and medical field with different specialties were represented in the group such as Psychiatric/Mental Health Nursing, Nursing Administration, and Medical-Surgical Nursing. To ascertain relevance, clarity, and completeness of the tool's experts elicited responses were either agree or disagree for the face validity and for content reliability, important, not important, and comments.

\section{Reliability:}

The required corrections and modifications were done and the researcher revised each tool and modifies some statement under supervision of the researcher supervisors. The required corrections and modifications were done as the following:

- Correct the linguistic and grammatical mistakes in some of the questions.

According to the reliability test results, the necessary modifications were done, as the font and format of tables were reprinted in clear forms.

Cronbach's Alpha reliability analysis.

\begin{tabular}{|l|c|c|c|c|c|}
\hline \multirow{2}{*}{ Tool } & \multicolumn{2}{|c|}{ Reliability } & \multicolumn{2}{c}{ Validity } & \multirow{2}{*}{ Internal consistency } \\
\cline { 2 - 5 } & $\begin{array}{c}\text { Reliability } \\
\text { Coefficient }\end{array}$ & $\begin{array}{c}\text { Cronbach's } \\
\text { Alpha }\end{array}$ & Self validate & $\begin{array}{c}\text { Content } \\
\text { valiantly }\end{array}$ & Good \\
\hline Knowledge & 0.885 & 0.768 & 0.968 & 0.931 & Good \\
\hline Practice & 0.814 & 0.816 & 0.850 & 0.922 & Good \\
\hline Attitude & 0.814 & 0.797 & 0.885 & 0.874 & Good \\
\hline Total questionnaire & 0.838 & 0.794 & 0.901 & 0.909 & \\
\hline
\end{tabular}

This tables show Alpha Cronbach's test which used to measure the internal consistency (Reliability of the used tool or instrument) the reliability score of tool as above is $(0.768$, $0.816,0.797$ and 0.794) for knowledge, practice, attitude and total questionnaire respectively, where the minimum reliability coefficient we need is $60 \%$, so is the reliability coefficient for all questions.

While validity score of tools is (0.931, $0.922,0.874$ and 0.909$)$ for knowledge, practice, attitude and total questionnaire 
respectively,this indicated high total internal consistency of the used tool.

\section{3-Pilot study:}

The pilot study was carried out for $10 \%$ of the sample to test the applicability of tools, ensure the clarity of the assessment sheet and estimate the time needed to fill in the sheet. Ten parents were selected and included in the main sample size as some modifications were done. The pilot study took two weeks duration from the beginning of July to 15 of July 2019. Then the tools were applied according to the findings of the pilot study.

\section{4-Field work:}

The actual fieldwork for the process of the data collection has consumed seven months started July, 2019 until end of January 2020. Before starting any step in the study, an official letter was addressed from the faculty of nursing, Ain-Shams University to the director of Elkhanka for psychiatric and mental health hospital.

Requesting his cooperation and permission to conduct the study. Once an official permissions were obtained from the principal person and the other authorized personnel from the various settings the researcher started the data collection.

All of the authorized personnel provided by the needed information about the study from the researcher. All parents who fit in the inclusion criteria were approached by the researcher to fill the questionnaire according to the following steps; the study was conducted during the morning shift from 11:00 am to 1:00 $\mathrm{pm}$. The researcher attended at the hospital and interviewed with parents individually after taking oral consent from nurse responsible for clinic and the doctor in patients waiting place three days weekly (Sundays, Tuesdays \& Wednesdays). Each interview with the available parent lasted about 30 to 40 minutes, depending on the response of interview.

\section{5-Limitations of the Study}

The study had several limitations.

Firstly, the sample was relatively small and the result can't be generalized. Secondly, it has been taken along time to collect subjects.

\section{6-Ethical considerations:}

Prior study conduction, ethical approval was obtained from the scientific research ethical committee of the faculty of nursing, Ain Shams University. The researcher also met the study subjects to explain the purpose of the study and to obtain their approval to participate. They were reassured about the anonymity and confidentiality of the collected data, which was used only for the purpose of scientific research. The subjects' right to withdraw from the study at any time was assured informed oral consent was obtained from every participant in the study after explaining the nature of the study.

\section{Administrative design}

An official approval was obtained from Dean of Faculty of nursing Ain-shams University, a letter containing the title and aim of the study was explained to the director of El khanka for psychiatric and mental health hospital to obtain the approval.

\section{Statistical design:}

Recorded data were analyzed using the statistical package for social sciences, version 20.0 (SPSS Inc., Chicago, Illinois, USA). Quantitative data were expressed as mean \pm standard deviation (SD). Qualitative data were expressed as frequency and percentage.

The following tests were done:

- Chi-square (x2) test of significance was used in order to compare proportions between qualitative parameters.

- Pearson's correlation coefficient (r) test was used to assess the degree of association between two sets of variables

- The confidence interval was set to $95 \%$ and the margin of error accepted was set to $5 \%$. So, the $\mathrm{p}$-value was considered significant as the following:

- Probability (P-value)

- P-value <0.05 was considered significant.

- P-value <0.001 was considered as highly significant.

- P-value >0.05 was considered insignificant. 


\section{RESULTS}

Table (1): Represents sociodemographic data of parents having school age children with enuresis it results that about nearly two third $(65.4 \%)$ in the age group30$<35$ with Mean \pm SD $31.27 \pm 5.94$, also majority of parents $(86.7 \%)$ having Intermediate education, but more than two third $(70.0 \%)$ of them were worker, so majority $(92.5 \%)$ are responsible for care of children together, also more than three quarter $(77.1 \%)$ of them don't suffer from a chronic disease that causes constant stress while caring for the child, and majority (89.6\%) of them their family income is hardly enough to include child care, also majority $(92.9 \%)$ of them were living in rural, majority $(82.1 \%)$ of other parent's children suffer from the enuresis, although majority (86.2\%) of bathrooms not located far from the child's room, and majority (85.4\%) of having enough lighting at night near the bathroom and the child room.

Table (2): This table represents the socio demographic data characteristics of school age children with enuresis according to their position in the family it results that slightly more than half of children with enuresis $(57.5 \%)$ were male sex, and about two third of them $(63.3 \%)$ were have male and female siblings, also more than one third of them $(35.4 \%)$ were the middle child between his siblings.

Fig. (1): This figure shows the socio demographic data characteristics of school age children with enuresis according to their weight it results the slightly more than one third $(40.8 \%)$ were between 26 to less than 41 $\mathrm{kg}$ with Mean \pm SD $34.53 \pm 5.87$.

Fig. (2): This figure represents school age children with enuresis high level of physical evaluation results that more than two third $(69.2 \%)$,followed by social assessment more than three quarters $(75.8 \%)$ and psychological evaluation results that more than two third $(70.8 \%)$.

Fig. (3): This figure indicates that parents total level of knowledge about enuresis results that less than two third $(59.2 \%)$ are average knowledge.

Figure (4): This figure represents parents having school age children with enuresis total level attitude about enuresis results that more than half $(55.0 \%)$ are natural attitude.

Figure (5): This figure indicates total levels of practice of parents having school age children with enuresis, shows that more than two third $(67.1 \%)$ of parents are incompetent practices.

Table (3): This table shows that there were statistical significant relations between the studied parents level of knowledge and their level of attitude, with $\mathrm{p}$-value $(\mathrm{p}<0.001)$.

Table (4): This table shows that there were highly statistical significant relations between the studied parents level of knowledge and their level of practice, with $\mathrm{p}$ value $(\mathrm{p}<0.001)$.

Table (5): This table shows that there were highly statistical significant relations between the studied parents level of practice and their level of attitude, with p-value $(\mathrm{p}<0.001)$.

Table (6): This table shows highly statistically significant correlation between total score of knowledge, attitude and practice. 
Table (1): Number and percentage of Socio-Demographic data characteristics for parents having school age children with enuresis according to their demographic data $(\mathrm{N}=240)$.

\begin{tabular}{|c|c|c|}
\hline Socio-Demographic data of parents & No. & $\%$ \\
\hline $\begin{array}{l}1 \text { - Parent responsible for care of child } \\
\text { Together } \\
\text { Father } \\
\text { Mother }\end{array}$ & $\begin{array}{c}222 \\
1 \\
17\end{array}$ & $\begin{array}{r}92.5 \\
0.4 \\
7.1\end{array}$ \\
\hline $\begin{array}{l}\text { 2- Residence } \\
\text { Urban } \\
\text { Rural }\end{array}$ & $\begin{array}{c}17 \\
223 \\
\end{array}$ & $\begin{array}{c}7.1 \\
92.9\end{array}$ \\
\hline $\begin{array}{l}\text { 3- Parents educational level } \\
\text { Iliterate } \\
\text { Read and write } \\
\text { Intermediate education } \\
\text { Higher education }\end{array}$ & $\begin{array}{c}15 \\
6 \\
208 \\
11\end{array}$ & $\begin{array}{c}6.3 \\
2.5 \\
86.7 \\
4.6\end{array}$ \\
\hline $\begin{array}{l}\text { 4. Family income sufficient to include child care? } \\
\text { Yes } \\
\text { No } \\
\text { hardly enough }\end{array}$ & $\begin{array}{r}12 \\
13 \\
215\end{array}$ & $\begin{array}{r}5.0 \\
5.4 \\
89.6\end{array}$ \\
\hline $\begin{array}{l}5 \text { - Parent's work } \\
\text { Working } \\
\text { non-permanent work }\end{array}$ & $\begin{array}{c}168 \\
72\end{array}$ & $\begin{array}{l}70.0 \\
30.0\end{array}$ \\
\hline $\begin{array}{c}\text { 6- Parents age } \\
25-<30 \text { years } \\
30-<35 \text { years } \\
35-<40 \text { years } \\
\geq 40 \text { years } \\
\end{array}$ & $\begin{array}{l}35 \\
157 \\
35 \\
13\end{array}$ & $\begin{array}{c}14.6 \\
65.4 \\
14.6 \\
5.4\end{array}$ \\
\hline Mean \pm SD & \multicolumn{2}{|c|}{$31.27 \pm 5.94$} \\
\hline $\begin{array}{l}\text { 7- Does the mother suffer from a chronic disease that causes } \\
\text { constant stress while caring for the child? } \\
\text { Yes } \\
\text { - If the answer is yes, indicate the type of disease. } \\
\text { - Cartilage inflammation of the neck and back } \\
\text { - Hypertension } \\
\text { - Diabetes } \\
\text { - No }\end{array}$ & $\begin{array}{c}55 \\
\\
24 \\
17 \\
14 \\
185\end{array}$ & $\begin{array}{l}22.9 \\
\\
9.99 \\
7.08 \\
5.83 \\
77.1\end{array}$ \\
\hline $\begin{array}{l}\text { 8- Does one of other parent's children suffer from the enuresis? } \\
\text { Yes } \\
\text { No }\end{array}$ & $\begin{array}{c}197 \\
43\end{array}$ & $\begin{array}{l}82.1 \\
17.9\end{array}$ \\
\hline $\begin{array}{l}\text { 9- Is the bathroom located far from the child's room? } \\
\text { Yes } \\
\text { No }\end{array}$ & $\begin{array}{c}33 \\
207\end{array}$ & $\begin{array}{l}13.8 \\
86.2\end{array}$ \\
\hline $\begin{array}{l}\text { 10- Is there enough lighting at night near the bathroom and the child } \\
\text { room? } \\
\text { Yes } \\
\text { No }\end{array}$ & $\begin{array}{c}205 \\
35\end{array}$ & $\begin{array}{l}85.4 \\
14.6\end{array}$ \\
\hline
\end{tabular}


Table (2): Number and percentage of socio demographic data characteristics of school age children with enuresis $(\mathrm{N}=240)$.

\begin{tabular}{||l|l|l||}
\hline Items & No. & $\%$ \\
\hline \hline Child Sex & & \\
Male & 138 & 57.5 \\
Female & 102 & 42.5 \\
\hline Sex of siblings & & \\
Lonely Family & 31 & 12.9 \\
Lonely Boy Among girls & 35 & 14.6 \\
Single girl between male brothers & 22 & 9.2 \\
He has male and female brothers & 152 & 63.3 \\
\hline The order of the child between brothers and sisters & & \\
The Biggest & 77 & 32.1 \\
The Middle & 85 & 35.4 \\
The Smallest & 78 & 32.5 \\
\hline
\end{tabular}

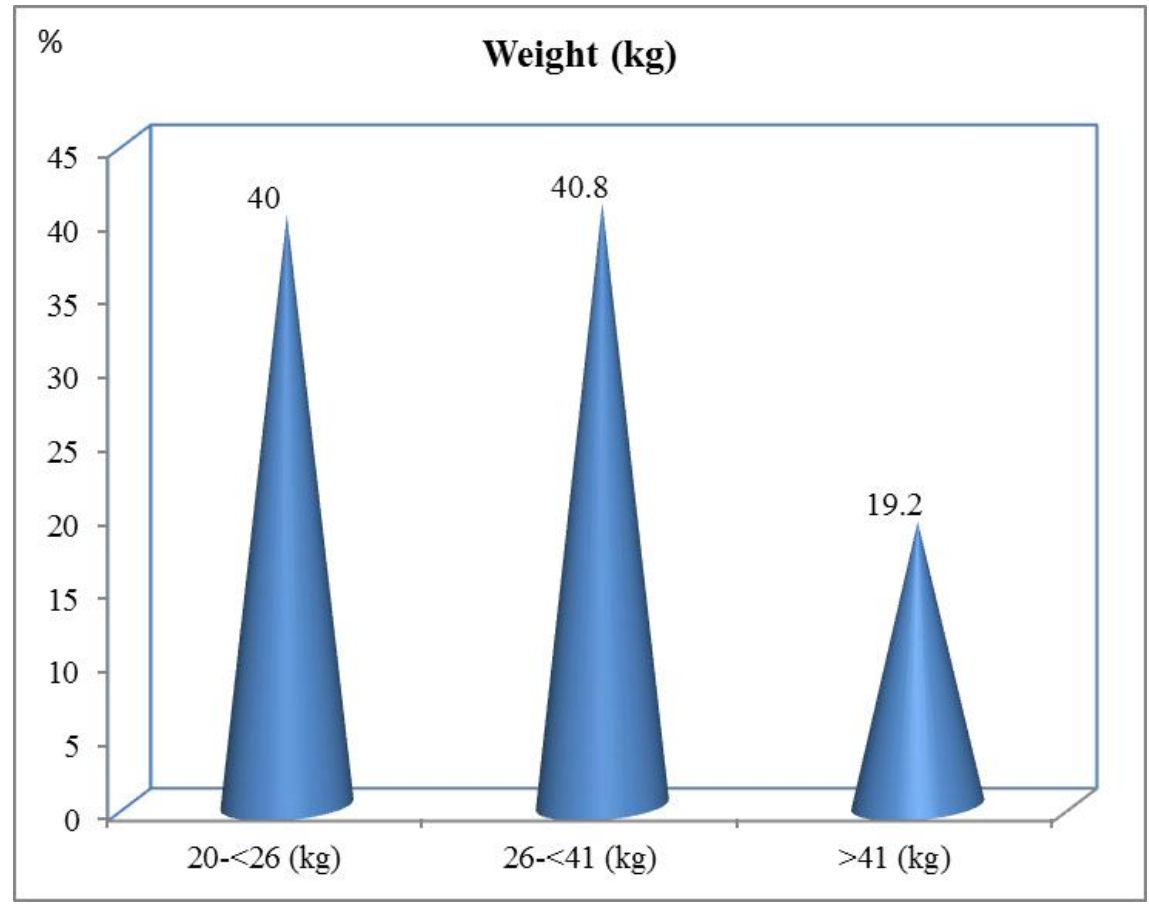

Figure (1): Number and percentage of socio demographic data characteristics of school age children with enuresis according to their weight. $(\mathrm{N}=240)$. 


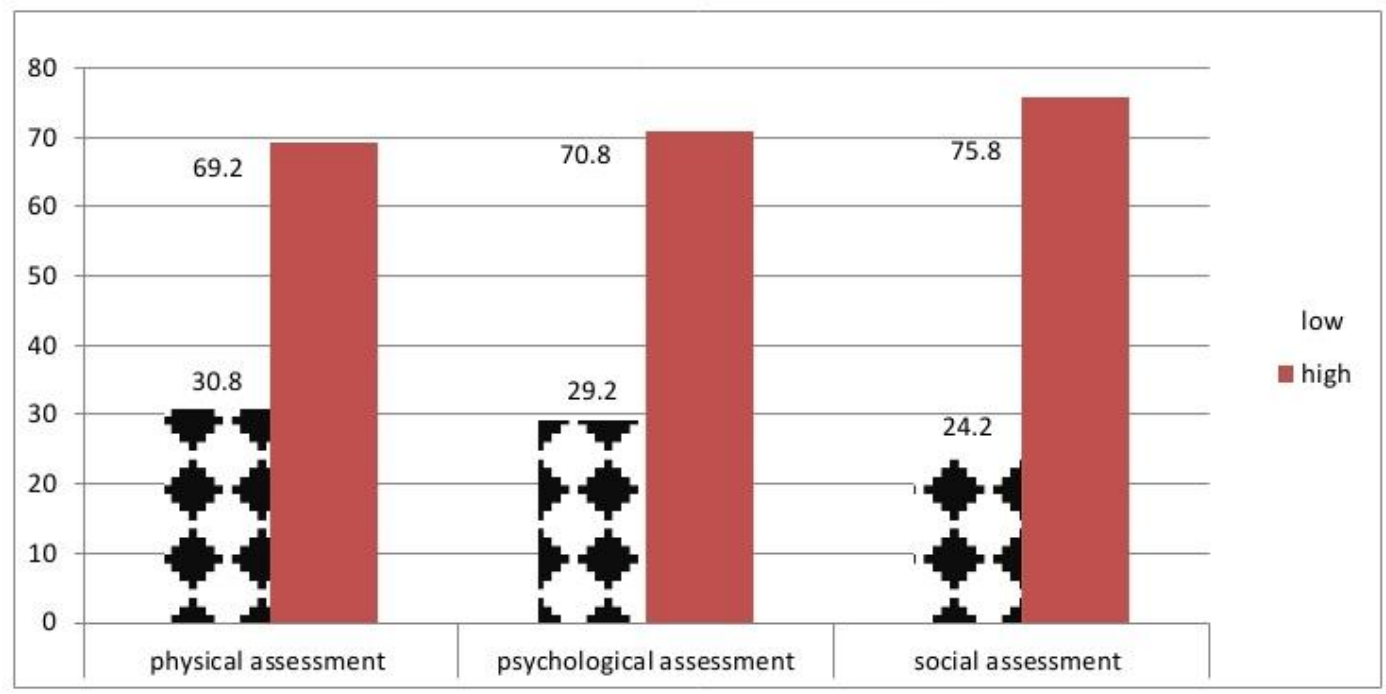

Figure (2): Number and percentage of distribution of school age children with enuresis according to their total level of physical, psychological and social assessment of school age children with enuresis answered by parents $(\mathrm{N}=240)$.

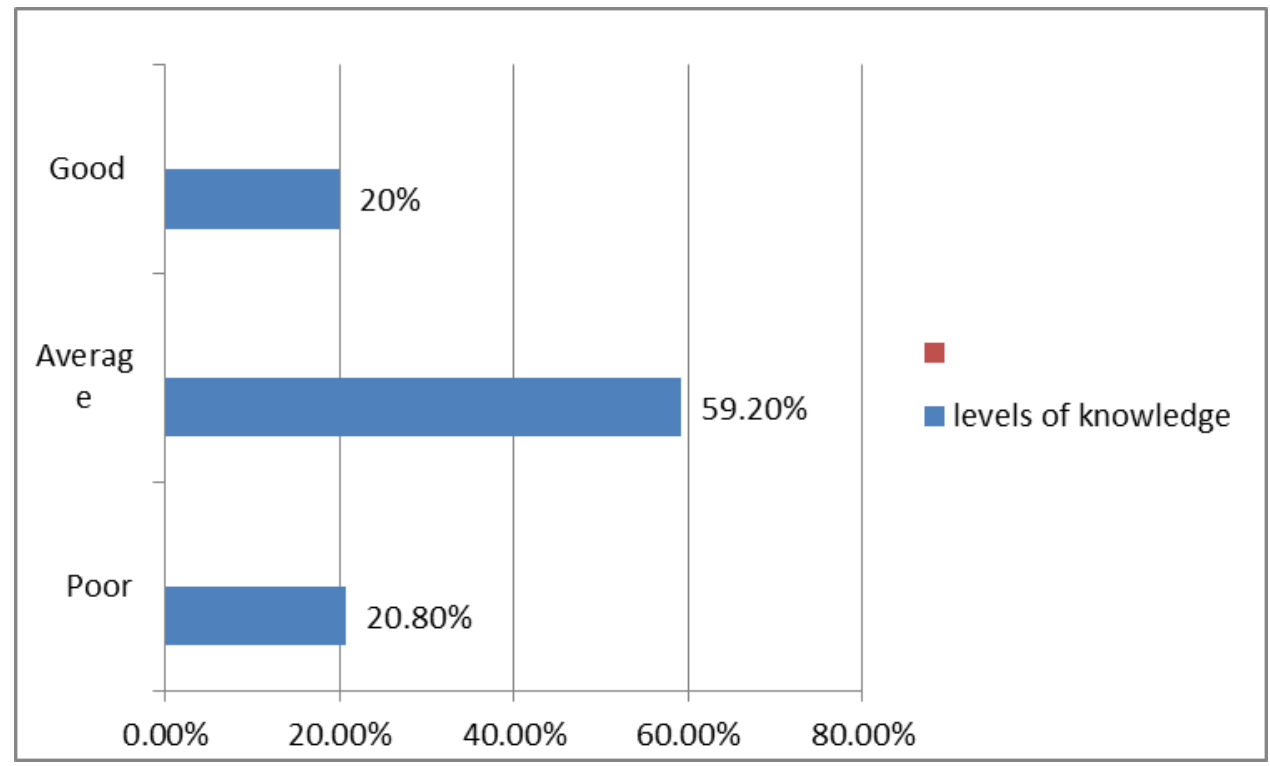

Figure (3): Awareness of Parents having school age children with enuresis related to total level of knowledge about enuresis. $(\mathrm{N}=240)$. 


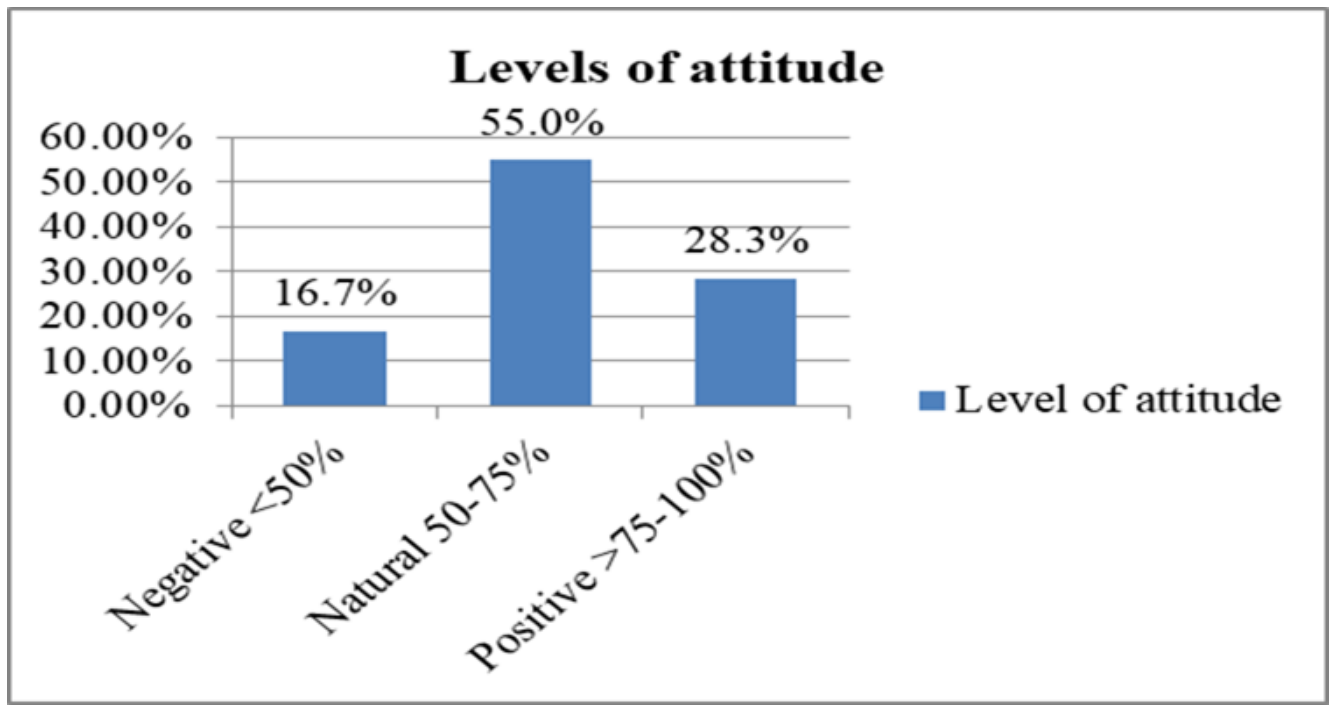

Figure (4): Awareness of Parents having school age children with enuresis related to total level attitude about enuresis $(\mathrm{N}=240)$.

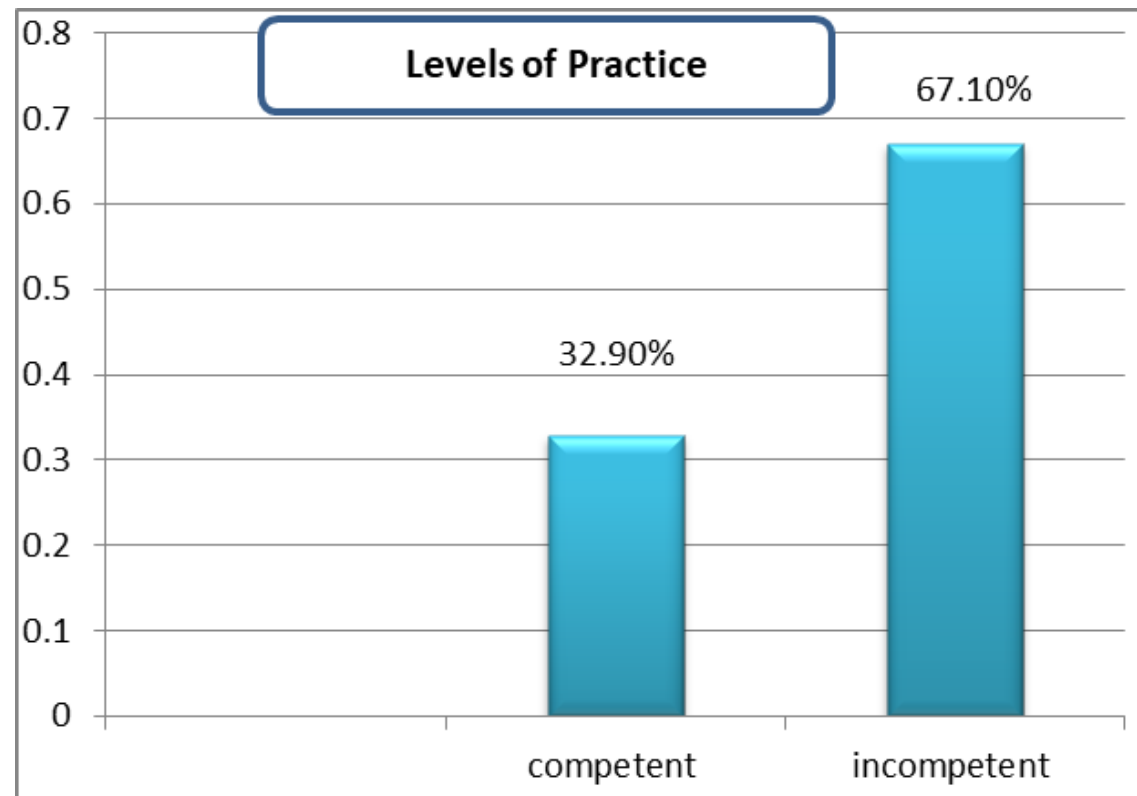

Figure (5): Awareness of Parents having school age children with enuresis related to their total levels of practice toward enuresis $(\mathrm{N}=240)$. 
Table (3): Relation between total level of attitude of parents having school age children with enuresis and their total level of knowledge $(n=240)$.

\begin{tabular}{|c|c|c|c|c|c|c|c|c|c|c|}
\hline \multirow{3}{*}{ Level of attitude } & \multicolumn{6}{|c|}{ Level of knowledge } & \multirow{2}{*}{\multicolumn{2}{|c|}{ Total }} & \multirow{2}{*}{\multicolumn{2}{|c|}{ Chi-square test }} \\
\hline & \multicolumn{2}{|c|}{ Poor } & \multicolumn{2}{|c|}{ Average } & \multicolumn{2}{|c|}{ Good } & & & & \\
\hline & No. & $\%$ & No. & $\%$ & No. & $\%$ & No. & $\%$ & $\mathrm{x} 2$ & p-value \\
\hline Natural & 6 & $12.0 \%$ & 124 & $87.3 \%$ & 2 & $4.2 \%$ & 132 & $55.0 \%$ & & \\
\hline Negative & 40 & $80.0 \%$ & 0 & $0.0 \%$ & 0 & $0.0 \%$ & 40 & $16.7 \%$ & & \\
\hline Positive & 4 & $8.0 \%$ & 18 & $12.7 \%$ & 46 & $95.8 \%$ & 68 & $28.3 \%$ & & \\
\hline Total & 50 & $100.0 \%$ & 142 & $100.0 \%$ & 48 & $100.0 \%$ & 240 & $100.0 \%$ & & \\
\hline
\end{tabular}

**p-value $<0.001 \mathrm{HS}$

Table (4): Relation between total level of practice of parents having school age children with enuresis and their total level of knowledge $(n=240)$.

\begin{tabular}{|c|c|c|c|c|c|c|c|c|c|c|}
\hline \multirow{3}{*}{ Level of practice } & \multicolumn{6}{|c|}{ Level of knowledge } & \multirow{2}{*}{\multicolumn{2}{|c|}{ Total }} & \multirow{2}{*}{\multicolumn{2}{|c|}{ Chi-square test }} \\
\hline & \multicolumn{2}{|c|}{ Poor } & \multicolumn{2}{|c|}{ Average } & \multicolumn{2}{|c|}{ Good } & & & & \\
\hline & No. & $\%$ & No. & $\%$ & No. & $\%$ & No. & $\%$ & $\mathrm{x} 2$ & alue \\
\hline Competent & 5 & $10.0 \%$ & 37 & $26.1 \%$ & 37 & $77.1 \%$ & 79 & $32.9 \%$ & & \\
\hline Incompetent & 45 & $90.0 \%$ & 105 & $73.9 \%$ & 11 & $22.9 \%$ & 161 & $67.1 \%$ & 57.322 & $<0.001 * *$ \\
\hline Total & 50 & $100.0 \%$ & 142 & $100.0 \%$ & 48 & $100.0 \%$ & 240 & $100.0 \%$ & & \\
\hline
\end{tabular}

**p-value $<0.001 \mathrm{HS}$

Table (5): Relation between total level of attitude of parents having school age children with enuresis and their total level of practice $(n=240)$.

\begin{tabular}{|c|c|c|c|c|c|c|c|c|}
\hline \multirow{3}{*}{ Level of attitude } & \multicolumn{4}{|c|}{ Level of practice } & \multirow{2}{*}{\multicolumn{2}{|c|}{ Total }} & \multirow{2}{*}{\multicolumn{2}{|c|}{ Chi-square test }} \\
\hline & \multicolumn{2}{|c|}{ Competent } & \multicolumn{2}{|c|}{ Incompetent } & & & & \\
\hline & No. & $\%$ & No. & $\%$ & No. & $\%$ & $\mathrm{x} 2$ & $\mathrm{p}$-value \\
\hline Natural & 29 & $36.7 \%$ & 103 & $64.0 \%$ & 132 & $55.0 \%$ & \multirow{4}{*}{48.78} & \multirow{4}{*}{$<0.001 * *$} \\
\hline Negative & 5 & $6.3 \%$ & 35 & $21.7 \%$ & 40 & $16.7 \%$ & & \\
\hline Positive & 45 & $57.0 \%$ & 23 & $14.3 \%$ & 68 & $28.3 \%$ & & \\
\hline Total & 79 & $100.0 \%$ & 161 & $100.0 \%$ & 240 & $100.0 \%$ & & \\
\hline
\end{tabular}

**p-value $<0.001 \mathrm{HS}$

Table (6): Correlation between total score of knowledge, attitude and practice of parents having school age children with enuresis using Pearson Correlation Coefficient $(n=240)$.

\begin{tabular}{|l|l|c|c|c|}
\hline \multicolumn{2}{|c|}{} & $\begin{array}{c}\text { Total score of } \\
\text { knowledge }\end{array}$ & $\begin{array}{c}\text { Total score of } \\
\text { attitude }\end{array}$ & $\begin{array}{c}\text { Total score of } \\
\text { practice }\end{array}$ \\
\hline \multirow{3}{*}{ Total score of knowledge } & $\mathrm{R}$ & & $.815^{* *}$ & $.417^{* *}$ \\
\cline { 2 - 5 } & $\mathrm{p}$-value & & 0.000 & 0.000 \\
\cline { 2 - 5 } & $\mathrm{N}$ & & 240 & 240 \\
\hline \multirow{3}{*}{ Total score of attitude } & $\mathrm{R}$ & $.815^{* *}$ & & $.332^{* *}$ \\
\cline { 2 - 5 } & $\mathrm{p}$-value & 0.000 & & 0.000 \\
\cline { 2 - 5 } & $\mathrm{N}$ & 240 & & 240 \\
\hline \multirow{3}{*}{ Total score of practice } & $\mathrm{R}$ & $.417^{* *}$ & $.332^{* *}$ & \\
\cline { 2 - 5 } & $\mathrm{p}$-value & 0.000 & 0.000 & \\
\cline { 2 - 5 } & $\mathrm{N}$ & 240 & 240 & \\
\hline
\end{tabular}

**. Correlation is significant at the 0.01 level (2-tailed).r-Pearson Correlation Coefficient

\section{DISCUSSION}

Enuresis is involuntary recurrent urination during the night in a sleep, which is common among children at the age of 5 or above. Another description of enuresis is as follows: It is unconscious urination after the age, at which bladder control usually occurs. Enuresis is a common clinical problem, which impairs the quality of lives of both the students and the parents. Consequently, emotional and learning problems occur due to the disease 
affecting the social life (Doganer, Aydogan, Ongel, Sari, Koc, \& Saglam, 2015).

Nocturnal enuresis is a frustrating problem to parents. The parents are typically the one responsible for the clean up after an accident and are typically charged with finding a cure for the problem. The parent's reaction of enuretic children is negatively affected; they have low general health concept, high anxiety and depression. These effects may lead parents to seek medical advice and treatment for their enuretic children. However, mothers preferred management strategies such as lifting, water restriction, regular voiding, and rewards rather than treatment interventions such as medication, alarm use, hypnosis, and physician advice (Rady, Elsayied, \& Elhafez, 2017).

This discussion deals with the following items:

In the present study, the majority of the studied parents their family income hardly enough to include child care. This could be explained as a negative correlation was found between monthly income level and the prevalence of enuresis. From the researcher point of view this could be due to high cost of care and life needs, These results agreement with the study achieved by ( Walle, Rittig, Tekgül, Austin, Shei-Dei Yang, Lopez, \& Van Herzeele, 2017) about "Enuresis: practical guidelines for primary care", who mentioned that the majority of studied sample had insufficient monthly income.

According to physical assessment via parents, the findings of the current study revealed that slightly less than two-third of children with enuresis were hyperactive. Also, more than half of them have lack of movement. Moreover, majority of them have physical weakness. From the researcher point of view, these results may be due to negative influence on everyday activities and those children are anxious or even depressed. These results are similar with the results of study performed by Traisman (2015) about "Enuresis: evaluation and treatment", who found that more than half of the studied school children were hyperactive. Also, more than two-thirds of them had physical problems.

Related to psychological assessment by parents, the findings of the current study revealed that slightly more than half of children with enuresis were have anxiety. Also, three quarters of them have low selfconfidence. Moreover, more than three quarter of them have stubbornness. From researcher point of view these results may be due to children feelings of stress, shame and try to cover up this disorder. These results are in the same line with the results of study performed by Gulisano, Domini, Capelli, Pellico \& Rizzo, 2017) about "Importance of neuropsychiatric evaluation in children with primary mono symptomatic enuresis", who demonstrated significantly higher total, low self-confidence, withdrawn, somatic complaint, anxious/depressed, and attention problems scores.

Regarding to sociality assessment by parents, the findings of the current study revealed that more than three quarters of children with enuresis were aggressive. Also, more than two third of them have isolation and introversion. From the researcher point of view, these results may be due to the negative impact of the child's psychological state on their social condition and capabilities to leave home with friends and family. These results are in agreement with the results of study performed by Iscan, \& Ozkayin (2020) about "Evaluation of health-related quality of life and affecting factors in child with enuresis", who showed that children with enuresis had lower emotional well-being scores, family relationship score and friendship score. Also this study showed that children with enuresis had higher level of aggressive.

Regarding to total level of knowledge about enuresis of parents having school age children with enuresis, the finding of the current study revealed that more than half of parents had average knowledge. These results are similar with (Duraphe, 2018) who carried a study to assess "Management of enuresis: Need to focus on parents' knowledge and practice", \& Osman, Ali \& Kamel, 2016) who carried a study to assess "Impact of an Educational Program on Mothers' Knowledge, Attitude and Practice regarding their Children with Nocturnal Enuresis" who found that more than half of the studied parents had satactory level of total knowledge about enuresis. 
According to total level of attitude about enuresis by child, the finding of the current study showed that more than half of the studied parents had natural attitude related to enuresis. Also, more than one quarter of them had positive attitude. While, less than one fifth of them had negative attitude. From researcher point of view these results could be attributed to poor awareness and lack of attending any training program about enuresis. Another explanation might be due to the lack of right and specific information about the disease on media such as television, newspapers, magazines, and etc. These results approved with the study performed by Osman et al. , 2016), who carried a study to assess "Impact of an Educational Program on Mothers' Knowledge, Attitude and Practice regarding their Children with Nocturnal Enuresis" who mentioned that nearly three quarters of the studied mothers had unsatisfactory attitude regarding to their children with nocturnal enuresis.

According to total level practice about enuresis by child, the finding of the current study showed that two third of parents were incompetent; while one third of them were competent. From researcher point of view these results could be attributed to the parents may be occupied by her responsibilities in their homes and with their other children and didn't have time to read about the disease. Those children need for special rehabilitative and behavioral programs dealing with their problems. Furthermore, these results may spot the light on the quality of services provided on the governmental hospitals and strengthen the role of the health care team especially the physician and the nurse in health education of the children and their caregivers regarding enuresis. These results approved with the study performed by (Essawy, El Sharkawy \& Basuony, 2017) about "Caregivers' Management for Their Children with Nocturnal Enuresis", who illustrated that highest percent of caregivers attain unsatisfactory score for their performance in provided care for their children with nocturnal enuresis.iIt may be due to large family size or mother`s working.

Regarding to the relation between total level of knowledge of parents having school age children with enuresis and their total level of attitude, the present study revealed that there were statistical significant relations between the studied parents' level of knowledge and their level of attitude. This might be explained as, satisfactory level of knowledge were higher among parents with positive attitude. This results approved with the study achieved by Elmubarak, (2014) about "Knowledge, Attitudes and Practices of Caregivers of children with Nocturnal Enuresis at HajaSakina Primary Health Centre, Omdurman, Khartoum State, Sudan", and revealed that there were statistical significant relations between the studied caregivers' knowledge and their attitude for children with Nocturnal Enuresis.

Regarding to the relation between total level of knowledge of parents having school age children with enuresis and their total level of practice, the present study revealed that there were statistical significant relations between the studied parents' level of knowledge and their level of practice. This might be explained as, satisfactory level of knowledge were higher among parents with competent practice. This results approved with the study achieved by Duraphe et al., (2018) who revealed that parents' knowledge had a significant effect on parents' practice level.

Regarding to the relation between total level of practice of parents having school age children with enuresis and their total level of attitude, the present study revealed that there were statistical significant relations between the studied parents' level of practice and their level of attitude. This might be explained as, competent level of knowledge were higher among parents with positive attitude. This results approved with the study achieved by Mohamed, El-Sheikh \& Noaman. (2019). about "Applying Health Education Learning Package for Mothers Regarding Nocturnal Enuresis", and revealed that there were statistical significant relations between the studied mothers' practice and their attitude regarding nocturnal enuresis.

Regarding the correlation between total score of knowledge, attitude and practice of parents having school age children with enuresis, the present study revealed that there 
was highly significant positive correlation between total score of knowledge, attitude and practice. This could be explained as satisfactory knowledge was more encountered among those parents with competent practice and positive attitude. Another explanation, these results mean that the parents knowledge had an effect on their practice and attitude, as when the parents have a satisfactory knowledge level regarding their children conditions; this will improve their role regarding care of their children. This result supported with the study performed by Ahmed \& Mohamed, (2018) about "Effect of Educational Module on Improving School-Age Children and their Parent's Knowledge and Behavior Intervention about Nocturnal Enuresis" and supported by Duraphe et al., (2018) who stated that there was positive correlation between parents' knowledge and their attitude and practice toward the child with enuresis.

The finding of the present study clarifies that there were statistical significant relations between the studied parents level of knowledge and their level of attitude, also there were statistical significant relations between the studied parents level of knowledge and their level of practice,and there were statistical significant relations between the studied parents level of practice and their level of attitude.

The study illustrated that there is statistically significant correlation between total score of knowledge, attitude and practice.

\section{Conclusion:}

Nearly less than two third of parents having school age children with enuresis have average level of knowledge, more than half of parents having school age children with enuresis have natural level of attitude, and more than two third of them are incompetent practice.

\section{Recommendations}

Based on the findings of the present study, it could be recommended that:

o Development of a health educational training program for mothers to enhancing their knowledge for caring their children with enuresis .

○ Nursing intervention program for developing parent 's practice when dealing with their children suffering from enuresis

o establishing training programs for parents to modify their behaviors when dealing with their children with enuresis .

\section{References}

Ahmed, H., \& Mohammed, R. (2018). Effect of Educational Module on Improving School-Age Children and their Parent's Knowledge and Behavior Intervention about Nocturnal Enuresis. International Journal of Nursing Care, 6(1), 26-38.

Alshahrani, A., Selim, M., \& Abbas, M. (2018): Prevalence of nocturnal enuresis among children in Primary Health Care Centers of Family and Community Medicine, PSMMC, Riyadh City, KSA. Journal of family medicine and primary care, 7(5), 937.

Anyanwu, O. U., Ibekwe, R. C., \& Orji, M. L. (2015). Nocturnal enuresis among Nigerian children and its association with sleep, behavior and school performance.

Chow, S.C., Shao, J. \& Wang, H. (2007): Sample size calculation in clinical research, Second edition. Chapman and Hall/ CRC Biostatistics Series, P: 389405.

Doganer, Y., Aydogan, U., Ongel, K., Sari, O., Koc, B., \& Saglam, K. (2015). The prevalence and sociodemographic risk factors of enuresis nocturna among elementary school-age children. Journal of family medicine and primary care, 4(1), 39.

Duraphe, V. (2018). Management of enuresis: Need to focus on parents' knowledge and practice. International Journal of Nursing Research (IJNR), 1(3), 139145.

Elbahnasawy T. H, Elnagar A. M (2015): Psychological impact of nocturnal enuresis on self-esteem of school 
children, American journal of nursing research, 2015, Vol. 3, No. 1, 14-20.

Elmubarak, A. (2014). Knowledge, Attitudes and Practices of Caregivers of children with Nocturnal Enuresis at HajaSakina Primary Health Centre, Omdurman, Khartoum State, Sudan (2014) (Doctoral dissertation, University of Gezira).

Essawy, M., El Sharkawy, A., \& Basuony, G. (2017): Caregivers' Management For Their Children With Nocturnal Enuresis. IOSR Journal of Nursing

Gulisano, M., Domini, C., Capelli, M., Pellico, A., \& Rizzo, R. (2017): Importance of neuropsychiatric evaluation in children with primary monosymptomatic enuresis. Journal of pediatric urology, 13(1), 36-e1.

Iscan, B., \& Ozkayin, N. (2020): Evaluation of health-related quality of life and affecting factors in child with enuresis. Journal of Pediatric Urology.and Health Science, 7(5), 12-23.

Mastro, K. A., Flynn, L., Millar, T. F., DiMartino, T. M., Ryan, S. M., \& Stein, M. H. (2019). Reducing anesthesia use for pediatric magnetic resonance imaging: The effects of a patient-and family-centered intervention on image quality, health-care costs, and operational efficiency. Journal of Radiology Nursing, 38(1), 21-27.

Meydan, E. A., Civilibal, M., Elevli, M., Duru, N. S., \& Civilibal, N. (2012). The quality of life of mothers of children with monosymptomatic enuresis nocturna. International urology and nephrology, 44(3), 655-659.

Mohamed, R., El-Sheikh, O., \& Noaman, A. (2019). Applying Health Education Learning Package for Mothers Regarding Nocturnal Enuresis. American Journal of Nursing, 7(4), 561573.

Odususi, V. D., \&Afolabi, I. S. (2019). Severiy level of enuresis among children and adolscents in Ado-Odo, Ota, Ogun state, Nigeria. In Journal of
Physics: Conference Series (Vol. 1378, No. 4, p. 042010). IOP Publishing.

Osman, Z., Ali, S., \& Kamel, N. (2016): Impact of an Educational Program on Mothers' Knowledge, Attitude and Practice regarding their Children with Nocturnal Enuresis. International Journa of Advanced Researchl, 4(6), 771-782.

Preston Smith MD(2016): The complex bed-wetting book Including a day time program for nighttime dryness,p13,chr 2,3rd edit .(2016).

Rady, H., Elsayied, H., \& Elhafez, A. (2017). The Relation between Parent's Perception and Perceived Competence of School Age Enuretic Children. Journal of Nursing and Health Science, 6(6), 42-54.

Raveena, R. (2019). A Clinical Study on the Role of Homoeopathic Medicine in Managing Nocturnal Enuresis in Children (Doctoral dissertation, Sarada Krishna Homoeopathic Medical College, Kulasekharam).

Tai, T., Tai, B., Chang, Y., \& Huang, K. (2017). Parental perception and factors associated with treatment strategies for primary nocturnal enuresis. Journal of Pediatric Urology, 13(3), 272-e1.

Traisman, E. (2015): Enuresis: evaluation and treatment. Pediatric Annals, 44(4), 133-137.

Tu, N. D., \& Baskin, L. S. (2016). Nocturnal enuresis in children: Management. Retrieved November, 27, 2018.

Tu, N. D., Baskin, L., \& Arnhym, A. M. (2017): Nocturnal enuresis in children: Etiology and evaluation. UpToDate, Post, TW (Ed), UpToDate, Waltham, MA.

Walle, J., Rittig, S., Tekgül, S., Austin, P., Shei-Dei Yang, S., Lopez, P., \& Van Herzeele, C. (2017). Enuresis: practical guidelines for primary care. British Journal of General Practice, 67(660), 328-329. 